УДК $332.142: 338.46$

DOI: $10.26693 /$ ahpsxxi2019.01.096

\title{
МОДЕЛІ РЕІНТЕГРАЦІї ОКУПОВАНИХ ТЕРИТОРІЙ: СВІТОВИЙ ДОСВІД ТА УКРАЇНСЬКИЙ ВАРІАНТ
}

\author{
Ніна Ржевсъка, \\ e-mail:rzhevska@ua.fm \\ ORCID: https://orcid.org/oooo-ooo2-7671-3221 \\ Національний авіаційний університет, \\ Украӥна, озо58, м. Київ, пр. Космонавта Комарова, 1
}

Стаття присвячена розкриттю сутності реінтеграцї окупованих та деокупованих територій, як повернення громадян до соціального, культурного, економічного та політичного життя краӥн їхнъого походження, аналізу поточного стану та специфіки збройного конфлікту на Сході Украӥни. Проаналізовано ї складові та інструменти реалізациї, представлено та оцінено іноземні моделі реінтеграції окупованих та деокупованих територій, встановлено ступінь їхньӧ відповідності для Украӥни та зроблено спробу віднайти найбільи ефективну модель для реінтеграцій Донбасу.

Ключові слова: реінтеграція, окуповані територӥ, деокуповані територї̈, державна стратегія реінтеграциї, модель реінтеграції

Постановка проблеми. Військова агресія на території Донецької та Луганської областей, з огляду на перспективу врегулювання та подолання його наслідків $\epsilon$ тривалою і затяжною. Гібридність зовнішнього втручання, інформаційна агресія, міжнародні домовленості щодо цих територій, що виконуються лише частково, чинник сепаратизму, зовнішньополітичні зобов'язання України, неоднорідна громадська думка стосовно проблем Донбасу та відсутність єдиної політичної позиції у цьому питанні - фактори, які нині перешкоджають пошукам оптимальної моделі реінтеграції Донбасу.

Окрім цього, на часі вироблення комплексної державної стратегії, якої потребують не тільки непідконтрольні Україні території Донецької та Луганської областей, а й - деокуповані частини регіону. Українська модель реінтеграції Донбасу має сприяти не тільки демілітаризації та відновленню державного контролю на цих територіях, а й запобігати виникненню сепаратистських рухів, стимулювати повернення та інтеграцію громадян в український інформаційний, культурний, економічний та політичний простір.

Проблема реінтеграції Донбасу залишається відкритою для громадських і політичних дискусій, а процес формування та стратегії втілення оптимальної моделі реінтеграції, яка би враховувала міжнародний досвід та специфіку військового конфлікту на Сході України, потребує фахового науково-дослідного та експертного супроводу.

Саме тому, при дослідженні означеної проблему, за мету ми ставимо:

- проаналізувати міжнародний досвід реінтеграції окупованих та деокупованих територій,

- встановити параметри найбільш ефективної модель для реінтеграції Донбасу.

Методи. Використовуючи структурно-функціональний підхід, формулюємо поняття «реінтеграція», визначаємо їі складові та інструменти реалізації, представляємо та оцінюємо іноземні моделі реінтеграції окупованих та деокупованих територій і встановлюємо їхню відповідність для України.

Використання критерію оцінки оптимальності системи Парето дає змогу вийти 3 пропозицією оптимальної моделі подолання збройної агресії на Сході України. 
Отримані результати теоретичного аналізу та прикладних досліджень можуть стати підгрунтям для практичних рекомендацій щодо впровадження української моделі реінтеграції окупованих та деокупованих територій.

За визначенням Міжнародної організації з міграції (МOM), реінтеграція - це повторне включення людини в соціальну групу чи процес (aвm. - своєрідна повторна соціалізація). Наприклад, включення мігранта в суспільство країни його походження або місця проживання. Отже, реінтеграція - це процес повернення громадян до соціального, культурного, економічного та політичного життя країн їхнього походження ${ }^{1}$.

Відповідно, реінтеграція пропонує можливість особистісної самодостатності, мати доступ до соціальних мереж і контактів та психосоціальне здоров'я. Для окремих осіб процес реінтеграції значно ускладнюється відсутністю доступу до ресурсів, що дозволяють отримати дохід. Отже, держава має враховувати випадки, коли найуразливіші мігранти через проблеми зі здоров'ям не можуть самостійно забезпечувати себе, а також - запропонувати альтернативи для реалізації базових потреб репатріантів.

Поглиблене трактування поняття «реінтеграція» міститься у документі, розробленому Центром документації та досліджень Управління Верховного комісара ООН у справах біженців (УВКБ ООН) - «Реінтеграція в перехідний період від війни до миру»².

Даний документ спрямований на забезпечення політичного підгрунтя для вирішення дилем реінтеграції. 3 цією метою пропонується розробка спільних стратегічних програм проведення багатосторонніх заходів, що сприяють сталому поверненню.

Розробка стратегії передбачає три основні етапи: аналіз політичного контексту, формулювання умов реконструкції та примирення і встановлення спільних керівних принципів багатосторонньої діяльності. Щоб усунути наявні недоліки у розумінні суті та значення реінтеграції, УВКБ ООН пропонує провести аналіз причин виникнення загроз національній безпеці, характеру конфлікту та механізмів регулювання і здатності держави до національного захисту, можливого впливу репатріації на процесу реконструкції та примирення 3 . Результати цього аналізу дозволять створеній стратегії визначатися з пріоритетними ключовими компонентами реінтеграції.

Також у документі представлено дві групи вагомих складових реінтеграції, поділених умовно на «відновлення» та «примирення». Щодо першої, це - задоволення негайних матеріальних потреб постраждалого від війни населення та осіб, які повернулися після зняття конфлікту; розмінування та роззброєння; відновлення пошкодженої інфраструктури; розширення сфери соціальних послуг та надання якісної освіти; зміцнення/реформування політичних інститутів та адміністративних структур; розширення виробництва та торгівлі.

Примирення ж включає моніторинг ситуації з дотримання прав людини; сприяння встановленню справедливості у сфері політичних, соціальних та економічних прав; запровадження правових механізмів покарання за злочини, пов'язані з конфліктом; демілітаризацію суспільства та реінтеграцію військових; укріплення/реформування системи цивільної поліції та судової системи; зміцнення структур громадянського суспільства та сприяння примиренню.

Найважливішим, за такого підходу, є досягнення консенсусу щодо принципів, якими слід керуватись у цих діях.

У 2014 р. ООН розробила «Оперативний посібник із комплексного роззброєння, демобілізації та реінтеграції (РДР)», де визначено принципи та стандарти системи РДР. Згідно його змістового наповнення, основою реінтеграції є соціальний та економічний процес, що не виключає вагомої значимості встановлення відносин довіри

\footnotetext{
${ }^{1}$ European University Institute. (2011). Return Migration and Development Platform. Retrieved from www.eui.eu/Research/Library/ResearchGuides/Economics/Statistics/DataPortal/DReMM\#Howtoacc essdata

${ }^{2}$ UNHCR's Centre for Documentation and Research (CDR). (1997.) Reintegration in the Transition from War to Peace. Retrieved from www.refworld.org/pdfid/3ae6b31f8.pdf

3 Ibidem.
} 
серед громадян, зміцнення спільнот та сприяння примиренню і зміцненню демократії4.

Реінтеграція має супроводжуватися важливими політичними заходами, що сприятимуть зміцненню миру та реалізації цілей РДР. Серед них - створення механізмів правосуддя перехідного періоду, реалізація політики примирення, ефективна правозахисна стратегія, створення нових політичних партій, зміна конституції, вибори, створення нової судової системи, сприяння належному врядуванню, реформування системи безпеки, забезпечення доступу до землі та кредитів, тощо. Саме тому стратегія повинна носити комплексний характер і мати на меті відновлення миру та людського розвитку5.

Ефективність реінтеграції може бути досягнута лише завдяки розвитку місцевих громад та досягненню балансу між державною допомогою і самостійними громадянськими ініціативами. Окрім заходів по відновленню та підвищенню якості соціальних послуг, інфраструктури та місцевої економіки, потрібно приділяти увагу сегментам проблеми, які саме спричинили конфлікт. Реінтеграція має призвести до зміцнення потенціалу держави та громадянського суспільства в зоні конфлікту. Для формування ж ефективної стратегії з реінтеграції, необхідно проаналізувати та врахувати причини виникнення загроз національній безпеці, характер конфлікту та механізми його врегулювання, здатність держави до національного захисту та можливий вплив репатріації на процес реконструкції та примирення.

Важливим етапом у виробленні комплексної стратегії реінтеграції території $\epsilon$ аналіз характеру військового протистояння, причин виникнення загроз національній безпеці та здатність держави до відновлення національної безпеки.

Військова агресія на Донбасі має декілька унікальних рис, з якими слід рахуватися при оцінюванні іноземних моделей реінтеграції та виробленні національної стратегії 3 реінтеграції окупованих та деокупованих територій. Зокрема, серед причин збройного протистояння на Сході України, такими є цивілізаційні та економічні фактори, а не етнічний чинник. Посиленню сепаратистського чинника посприяло незадовільне соціально-економічне становище регіону, низький рівень політичної освіти та культури місцевих мешканців, пасивність громадянського суспільства, жорстка ієрархічна організація влади на місцях та російський інформаційний впливб.

Слід наголосити, що лінія розмежування на Донбасі - це результат воєнних дій, а не політичного чи етнічного розподілення. Військова агресія на Сході України характеризується високим рівнем зовнішнього вторгнення. Життєздатність, так званих, «ДНР/ЛНР» забезпечується шляхом фінансової, військової та політичної підтримки Росії, що поставляє війська та озброєння через неконтрольовану ділянку кордону. Росія, заперечуючи свій вплив, продовжує військове втручання та інші дії по дестабілізації України, що не дає можливості останній розв’язати конфлікт на своїх умовах, оскільки ОРДЛО перебувають під фактичним політичним та військовим контролем Росії.

Прикладом компромісу заради збереження територіальної цілісності держави 6 Боснійська модель, заснована на федералізації. Нерідко саме з Дейтонськими угодами, що сприяли завершенню трирічної війни у Боснії та Герцеговині, порівнюють мінський процес, що пропонує врегулювання конфлікту на Донбасі завдяки створенню «особливого порядку місцевого самоврядування в окремих районах Донецької та

\footnotetext{
4 United Nations Disarmament, Demobilization and Reintegration Resource Centre, UN DDR. (2014). Operational guide to the integrated disarmament, demobilization and reintegration standards. Retrieved from https://www.unddr.org/uploads/documents/Operational\%2oGuide.pdf 5 UN DDR. Inter-Agency Working Group on Disarmament, Demobilization and Reintegration. (2005). DDR briefing note for senior managers on the integrated disarmament, demobilization and reintegration standards. Retrieved from http://unddr.org/uploads/documents/SMN-FINAL.pdf ${ }^{6}$ Філіпчук, В., Октисюк, А., Поворозник, В., Ярошенко, Є. (2016). Моделі і ціна врегулювання конфлікту на Донбасі: міжнародний досвід та украӥнсъкі реалї̈. Київ: Міжнародний центр перспективних досліджень, 4-10.
} 
Луганської областей». Боснійська модель врегулювання спрямована радше на інтерналізацію конфлікту, ніж ліквідацію конфліктного потенціалу7.

Та, Мінські угоди, на відміну від Дейтонських, не містять двох важливих елементів, що послаблює можливості України. Йдеться про те, що Дейтонські угоди, на відміну від Мінських, не передбачали амністію учасникам збройних формувань, причетним до воєнних злочинів проти людяності, $\mathrm{i}$, друге - на територію БіГ було введено військовий контингент НАТО з підтримання миру, що згодом був замінений на сили EUFOR Altheа під егідою ЄC.

Без відновлення контролю над державним кордоном і введення міжнародного миротворчого контингенту на Донбас, амністія бойовиків та проведення виборів в ОРДЛО за українським законодавством, є значно гіршими умовами врегулювання для України, ніж для БіГ за результатами Дейтонських угод8.

Загалом, серед переваг боснійської моделі - збереження територіальної цілісності в межах довоєнних кордонів і заощадження ресурсів на воєнних діях, можливості для діалогу та примирення в рамках єдиної держави і доступ до міжнародних кредитів, необхідних для відбудови постраждалих районів. Та, з іншого боку, відсутність консенсусу при прийнятті важливих державних рішень, зокрема зовнішньополітичних, високий рівень втручання зовнішніх гравців у внутрішні процеси, загроза нових сепаратистських рухів та збереження конфліктного потенціалу є значними перешкодами для національної безпеки та ефективного функціонування держави.

Ще одна модель, до якої часто звертаються українські експерти - хорватська. Якщо боснійська модель апелює до мирних переговорів та досягнення компромісу, то хорватська грунтується на односторонній дії та силовій перевазі.

Сучасна ситуація в Україні та криза в Хорватії у 1990-х мають кілька подібних рис. По-перше, обидві країни зіштовхнулися з самопроголошеними утвореннями, де локальна ідентичність слабо пов'язана з ідеями хорватської та української державності, а також - із європейським цивілізаційним вектором. Так, більшість населення Сербської Країни прагнули приєднатись до «Великої Сербії», а ОРДЛО - стати складовою «русского мира». По-друге, урядам Хорватії та України були запропоновані плани мирного врегулювання, вироблені зовнішніми гравцями та спрямовані на запобігання гарячої фази конфлікту більше, аніж на його врегулювання. При цьому, від Хорватії, як наразі від України, вимагали надати широку автономію для Сербської Країни, однак ці поступки не сприймалися абсолютною більшістю мешканців цих країн.

Водночас, існують суттєві відмінності, що ускладнюють імплементацію хорватської моделі в Україні: військово-політичний потенціал Сербії в 1990-х, що підтримувала Сербську Країну, не можна порівнювати із воєнною силою Росії, яка здійснила військове вторгнення і надає пряму та непряму військову допомогу так званим ДНР/ЛНР; Сербія на той момент була масштабно залучена до війни в сусідній БіГ, що поглинала значну частину їі ресурсів. В свою чергу, Росія також одночасно залучена у війни на Донбасі та Сирії, проте її присутність у зонах конфлікту забезпечується незначним військовим контингентом; сепаратистські утворення різняться географією конфлікту. Так, Сербська Країна межувала з БіГ, а не з Сербією, що ініціювала конфлікт, тоді, як так звані ДНР/ЛНР контролюють понад 400 км українськоросійського кордону, через який постачається зброя та інші ресурси 9 .

\footnotetext{
7 Філіпчук, В., Октисюк, А., Поворозник, В., Ярошенко, Є. (2016). Моделі $і$ ціна врегулювання конфлікту на Донбасі: міжнародний досвід та українсъкі реалї. Київ: Міжнародний центр перспективних досліджень, 11-12.

${ }^{8}$ Октисюк, А. (2016, 12 августа). Последствия крымской «диверсии»: Украину ждут четыре сценария развития событий. Апостроф. Retrieved https://apostrophe.ua/article/politics/2016-08-12/posledstviya-kryimskoy-diversii-ukrainu-jdutchetyire-stsenariya-razvitiya-sobyitiy/6735

9 Буняк, Р. (2016, 18 квітня). Війна у Хорватії: ліквідація сепаратистів за 84 години і здача героїв. Retrieved from https://fakty.com.ua/ua/svit/20160418-1581913/
} 
Саме тому хорватську модель складно адаптувати до українських реалій. Значні військові втрати, жертви серед цивільного населення, масштабні руйнування, високий рівень зовнішньої інтервенції та поразки, політична, економічна дестабілізація і загроза міжнародної ізоляції є ризиками впровадження хорватської моделі.

Ще одна модель вирішення конфлікту - пакистанська. Орієнтація на таку модель зумовлена слабкою перспективою повернення територій ОРДЛО силовим шляхом і суспільним небажанням їхної реінтеграції на умовах РФ. Пакистанська модель сформувалась як результат затяжних та кривавих конфліктів, коли держава усвідомила нездатність перемогти сили сепаратистів воєнними методами і прийшла до висновку, що ресурси, витрачені на утримання нелояльної території, значно перевищують потенційні вигоди. Історія показує, що держави вдавалися до пакистанської моделі, переважно, під тиском тривалих громадянських воєн.

Пакистанська модель дійсно дозволяє позбавитись територіального анклаву, де проживає здебільшого нелояльне до центру населення, позбавити нелояльну територію можливості впливати на внутрішню та зовнішню політику держави і заощадити військові та фінансові ресурси. Водночас, вона провокує втрату прямого доступу до природних ресурсів, промислових об’єктів та інфраструктури на цих територіях, негативне ставлення як з боку суспільства, так і з боку міжнародної спільноти. Окрім того, такі дії можуть спровокувати поширення сепаратизму в інших регіонах і викликати внутрішню дестабілізацію.

Найпривабливішим, хоч і найскладнішим варіантом довготривалого вирішення територіальної проблеми залишається німецька модель. Вона передбачає повернення відмежованих територій, на довоєнних умовах, шляхом мирних переговорів із залученням зовнішніх гравців. Ї̈ привабливість полягає в тому, що повернення втрачених територій відбувається шляхом застосування не воєнної, а «м'якої» сили, що означає визнання іншою стороною переваг політичної та економічної системи ініціатора об'єднання.

Шанси на такий сценарій суттєво зростуть, якщо Україна протягом наступних років зможе побудувати ефективну політичну, економічну та правову модель держави. Успіх України на цьому шляху неодмінно сприятиме збільшенню політичних та економічних контрастів між становищем контрольованих та неконтрольованих територій. Враховуючи нестійку ідентичність більшості мешканців ОРДЛО, реформування та модернізація України може значно послабити проросійські погляди та посилити проукраїнські настрої серед населення непідконтрольних територій, створивши тим самим запит на реінтеграцію по інший бік лінії розмежування.

Однак, і за умов побудови ефективної держави зберігається потреба в зміні позиції РФ, що фактично контролює бойовиків і управляє військовими діями. Потрібно багато зусиль та часу, перш ніж Росія під тиском міжнародних санкцій, економічних дисбалансів, соціальних протестів та напруження буде вимушена скоротити військовий бюджет, створюючи військовий і політичний вакуум на території Донбасу, підконтрольній проросійським бойовикам.

Сильними сторонами німецької моделі є опора на «м'яку силу», замість військової, наявність згоди на об'єднання та орієнтованість на населення, яке має нестійку ідентичність. За такої моделі з'являється можливість вирішення територіальної проблеми на умовах переможця, зростання легітимності політичної еліти та державних інституцій, створення сприятливих умов для примирення, миротворчості та збільшення впливу держави на міжнародній арені. Однак, така модель залишає значну залежність від позиції зовнішніх гравців і загрозу появи нелояльних суспільнополітичних груп після об’єднання.

Збройний конфлікт на Донбасі має декілька унікальних рис, що не дозволяють повністю адаптувати іноземні моделі реінтеграції. Так, наявний чинник сепаратизму в Україні, на відміну від інших держав, має політичний характер, інспірований та підтримуваний іншою державою - Російською Федерацією. Лінія розмежування не зумовлена етнічними, релігійними чи ідеологічними чинниками, а $\epsilon$ результатом 
військових дій. Самопроголошені на українській території республіки, функціонують за рахунок фінансової, військової та політичної підтримки РФ, що, в свою чергу, заперечує своє втручання в конфлікт та дестабілізацію України.

Отже, в підсумку оцінки можливостей проаналізованих моделей маємо наступне:

- боснійська модель, хоч і може призвести до збереження територіальної цілісності в межах довоєнних кордонів і заощадити ресурси, не вирішує проблеми сепаратизму, а лише підвищує ризик внутрішньої дестабілізації та обмеження прийняття важливих державних рішень шляхом інтеграції нелояльних угрупувань в український політичний простір;

- хорватська модель може призвести до значних військових втрат, політичної та економічної дестабілізації та міжнародної ізоляції;

- пакистанська модель, що грунтується на відмові від територій, неприйнятна через ризики для національної безпеки та економіки, поширення сепаратизму в інших регіонах і негативне ставлення з боку суспільства.

- i, нарешті, німецька модель, хоча й має значну кількість переваг, але потребує великого проміжку часу, зусиль (в нашому випадку - колосальних) щодо ефективного розвитку держави, єдиної політичної стратегії та змін у політиці держави агресора.

Саме тому, Україна потребує власної моделі, яка би враховувала національні особливості.

Вироблення комплексної стратегії з реінтеграції Донбасу та громадян, які проживають на цих територіях, наразі, є актуальним питанням для України.

Одним із кроків вирішення даної проблеми стало прийняття Закону України «Про особливості державної політики із забезпечення державного суверенітету України над тимчасово окупованими територіями в Донецькі та Луганській областях» 18 січня 2018 року10.

Згідно Закону, цілями державної політики із забезпечення державного суверенітету України на тимчасово окупованих територіях у Донецькій та Луганській областях є:

- звільнення тимчасово окупованих територій у Донецькій і Луганській областях та відновлення на цих територіях конституційного ладу;

- захист прав, свобод і законних інтересів фізичних та юридичних осіб;

- забезпечення незалежності, єдності та територіальної цілісності України.

Щоб окреслити параметри можливої моделі, показати шляхи реінтеграції Донбасу, які би підтримувало саме суспільство, та виявити тренди у зміні громадської думки 3 цього приводу, ми скористалися результатами загальнонаціонального дослідження Фонду «Демократичні ініціативи» ім. Ілька Кучеріва і соціологічної служби Центру Разумкова 2018 року ${ }^{11}$.

У результаті порівняльного аналізу настроїв і думок щодо тем, пов'язаних із конфліктом та військовою агресією на Сході України, сценаріїв його вирішення на підконтрольних Україні територіях Луганської та Донецької областей та в інших регіонах України, було визначено цілу низку спільних проблем, компромісне врегулювання яких уможливить вироблення єдиної державної політики щодо реінтеграції Донбасу:

1. Близько половини громадян на підконтрольних територіях Донбасу та у інших регіонах України вважають, що для відновлення миру варто погоджуватись на компроміси, але не на всі (52\% та 36,9\% відповідно).

2. Виявилося, що частка прихильників ідеї більшої автономії Донбасу в складі України в інших iï регіонах є значно більшою, ніж частка прихильників такої ідеї на підконтрольних територіях Луганської та Донецької областей (25\% проти 14\% відповідно).

1о Верховна Рада України. (2018). Закон України Про особливості державної політики із забезпечення державного суверенітету України на тимчасово окупованих територіях у Донецькій та Луганській областях. Retrieved from https://zakon.rada.gov.ua/laws/show/2268-19 ${ }^{11}$ Фонд «Демократичні ініціативи» імені Ілька Кучеріва. (2018, 28 грудня). Підсумки-2018: громадсъка думка. Retrieved from https://dif.org.ua/article/pidsumki-2018-gromadska-dumka 
3. Компромісом щодо торгівлі з окупованими територіями Донбасу може стати дозвіл на торгівлю критично важливими товарами харчування і товарами першої необхідності - таку ідею підтримують 47\% громадян України. Таке рішення зменшить частку мешканців Донбасу, які вважають, що блокада погіршила умови життя для звичайних людей (наразі - таких більшість).

4. Найбільші можливості на нині мають заходи гуманітарної, освітньої та культурної політики, адже 60\% українців підтримують спрощення доступу до навчання в українських освітніх закладах для мешканців непідконтрольних територій; загалом 44\% українців доцільним вважають збереження гуманітарних відносин із цими територіями. У свою чергу, результати опитування на Донбасі демонструють високу затребуваність гуманітарних і культурних проектів та відповідної інформації.

У підсумку, спільною залишається проблема відсутності серед громадян єдиної позиції щодо оптимального шляху відновлення територіальної цілісності України, що за умови врахування наявності такого запиту серед усіх українських громадян та вищезазначених спільних точок порозуміння формує найбільш оптимальні, за весь період збройного протистояння, умови для створення комплексної державної політики $з$ цього питання, що має бути підтримана якісним інформаційним та політичним супроводом.

Для розв’язання конфліктної ситуації, що склалася на Сході України, пропонуємо розв'язки, які виявилися оптимальними (у результаті оцінювання згідно принципу оптимальності Парето) для всіх учасників досліджуваного конфлікту.

Учасники конфлікту на Сходу Україні:

1. $\mathrm{S} 1$ - Україна

2. $\mathrm{S} 2$ - Російська Федерація

3. S3 - Свропейський Союз

4. $\mathrm{S} 4$-Самопроголошені Республіки, так звані, ЛНР та ДНР

Можливі стратегї учасників:

$\mathrm{X}_{11}$ - Загальна мобілізація та початок активних бойових дій за повернення територій;

$\mathrm{X}_{12}$ - Введення міжнародної миротворчої місії ООН та реалізація безпекових положень мінських домовленостей;

$\mathrm{X}_{13}$ - Надання особливого статусу Донбасу, амністія бойовиків та проведення виборів на Донбасі;

$\mathrm{X}_{14}$ - Замороження конфлікту;

$\mathrm{X}_{21}$ - Пряме військове вторгнення до України;

$\mathrm{X}_{22}$ - Реалізація Мінських домовленостей;

$\mathrm{X}_{23}$-Легітимізація терористів через виборчий процес із метою дестабілізації та федералізації України;

$\mathrm{X}_{31}$ - Посилення санкцій проти Російської Федерації;

$\mathrm{X}_{32}-$ Зняття санкцій з РФ;

$\mathrm{X}_{33}$ - Надання військової допомоги Україні;

$\mathrm{X}_{41}$ - Участь та забезпечення виборів на цих територіях;

$\mathrm{X}_{42}-$ Ескалація конфлікту заради незалежності.

За даними про учасників та їхніми стратегіями побудовано Таблицю 1, 3 урахуванням оцінки вагомості кожної стратегї̈ за шкалою від 1 до 5, (де 1 - це мінімальний виграш, а 5 - максимальний виграш) та ваги кожного учасника (шкала - від о до 1). $\beta_{\mathrm{i}}$ - ваговий коефіцієнт, що описує вплив конкретного учасника на розвиток досліджуваної конфліктної ситуації. 
Експертне оцінювання стратегій учасників конфлікту

\begin{tabular}{|c|c|c|c|c|}
\hline & S1 - Україна & $\mathrm{S} 2-\mathrm{P} \Phi$ & $\mathrm{S}_{3}-\mathrm{EC}$ & $\mathrm{S}_{4}-$ ЛНР і ДНР \\
\hline $\mathrm{X}_{11}$ & 3 & 3 & 1 & 4 \\
\hline $\mathrm{X}_{12}$ & 5 & 3 & 5 & 1 \\
\hline $\mathrm{X}_{13}$ & 1 & 4 & 5 & 5 \\
\hline $\mathrm{X}_{14}$ & 2 & 3 & 4 & 4 \\
\hline $\mathrm{X}_{21}$ & 1 & 3 & 1 & 4 \\
\hline $\mathrm{X}_{22}$ & 5 & 3 & 5 & 2 \\
\hline $\mathrm{X}_{23}$ & 2 & 5 & 3 & 5 \\
\hline $\mathrm{X}_{31}$ & 5 & 1 & 3 & 2 \\
\hline $\mathrm{X}_{32}$ & 1 & 5 & 3 & 5 \\
\hline $\mathrm{X}_{33}$ & 5 & 1 & 3 & 1 \\
\hline $\mathrm{X}_{41}$ & 3 & 4 & 3 & 4 \\
\hline $\mathrm{X}_{42}$ & 1 & 3 & 1 & 4 \\
\hline$\beta_{\mathrm{i}}$ & 0,30 & 0,30 & 0,20 & 0,20 \\
\hline
\end{tabular}

Ми побудували таблицю реалізації можливих стратегій кожного учасника, з урахуванням ваги кожного (Додаток А) та підрахували мінімально гарантований результат для кожного з учасників:

$\left(\mathrm{S}_{1}\right) \alpha_{1=} 5^{*} \mathrm{O}, 3 \mathrm{O}+1^{*} \mathrm{O}, 3 \mathrm{O}+1^{*} \mathrm{O}, 2 \mathrm{O}+1^{*} \mathrm{O}, 2 \mathrm{O}=2,2$

$\left(\mathrm{S}_{2}\right) \alpha_{2}=5^{*} \mathrm{O}, 3 \mathrm{O}+3^{*} \mathrm{O}, 3 \mathrm{O}+1^{*} \mathrm{O}, 2 \mathrm{O}+3^{*} \mathrm{O}, 2 \mathrm{O}=3,2$

$\left(\mathrm{S}_{3}\right) \mathrm{a}_{3}=3^{*} \mathrm{O}, 2 \mathrm{O}+1^{*} \mathrm{O}, 3 \mathrm{O}+1^{*} \mathrm{O}, 3 \mathrm{O}+1^{*} \mathrm{O}, 2 \mathrm{O}=1,4$

$\left(\mathrm{S}_{4}\right) \mathrm{a}_{4}=4^{*} \mathrm{O}, 2 \mathrm{O}+1^{*} \mathrm{O}, 3 \mathrm{O}+2^{*} 0,30+1^{*} 0,20=1,9$

Як висновок, можна констатувати, що серед множини раціональних рішень, оптимальної розв'язки досліджуваної конфліктної ситуації не виявлено. Для її вирішення необхідно вводити посередників, додаткові стратегії учасників або проводити роботу 3 метою переоцінки учасниками власних стратегій та стратегій інших учасників.

Відповідно до принципу оптимальності Парето жодна з загальних стратегій, що озвучуються сторонами конфлікту, не може призвести до оптимального вирішення конфлікту.

Отже, нині нагальною потребою є наявність єдиної державної стратегії щодо вирішення збройного конфлікту на Сході України та ліквідації його наслідків, серед яких - реінтеграція цих територій, що охоплюватиме компроміси, з якими погоджуються українські громадяни, ключові рішення стосовно не тільки військового, а й політичного, економічного та інформаційного виміру конфлікту та міжнародний досвід реінтеграції територій.

Комплексна стратегія 3 відновлення територіальної цілісності та реінтеграції Донбасу охоплюватиме необхідні дії щодо всіх вимірів конфлікту, компроміси, що мають суспільну підтримку, врахує поточні внутрішньополітичні на міжнародні особливості процесу, міжнародний досвід із відновлення миру та реінтеграції, сформує єдиний державний підхід до вирішення цієї проблеми.

Висновки. Збройний конфлікт на Донбасі має декілька унікальних рис, які не дозволяють адаптувати повністю іноземні моделі реінтеграції. Так, наявний чинник сепаратизму в Україні, на відміну від інших держав, має політичний характер, інспірований та підтримуваний Російською Федерацією. Лінія розмежування - не зумовлена етнічними, релігійними чи ідеологічними чинниками, а є результатом військових дій. Самопроголошені на українській території республіки, функціонують за рахунок фінансової, військової та політичної підтримки РФ, яка, в свою чергу, заперечує своє втручання в конфлікт та дестабілізацію України.

Проблемою залишається відсутність серед громадян єдиної позиції щодо оптимального шляху відновлення територіальної цілісності України, яка би окреслила чіткі вимоги до формування комплексної державної політики з цього питання. 
Згідно принципу оптимальності Парето, жодна з загальних стратегій, що озвучуються сторонами конфлікту, не може призвести до оптимального його розв'язання. Результати ж дослідження, вкотре, підтвердили потребу переоцінки наявних стратегій, їхнього комплексного опрацювання та доповнення.

Українська модель відновлення територіальної цілісності та реінтеграції Донбасу, має грунтуватися на ключових позиціях та компромісах, що мають позитивний міжнародний досвід застосування та підкріплені національним і міжнародним правовим та військовим потенціалом, а також таких, що мають максимальні шанси на формування єдиної позиції України та її міжнародних партнерів і отримання позитивного результату припинення військової агресії зі сторони РФ.

\section{REFERENCES}

Buniak, R. (2016, 18 kvitnia). Viina u Khorvatii: likvidatsïa separatystiv za 84 hodyny $i$ zdacha heroiv. [War in Croatia: elimination of separatists in 84 hours and release of heroes]. Retrieved from https://fakty.com.ua/ua/svit/20160418-1581913/ [in Ukrainian]

European University Institute. (2011). Return Migration and Development Platform. Retrieved from www.eu [in English]

Fond «Demokratychni initsiatyvy» imeni Ilka Kucheriva. (2018, 28 грудня). Pidsumky-2018: hromadska dumka. [The results 2018: Civil point of view]. Retrieved from https://dif.org.ua/article/pidsumki-2018-gromadska-dumka [in Ukrainian]

Filipchuk, V., Oktysiuk, A., Povoroznyk, V. \& Yaroshenko, Ye. (2016). Modeli i tsina vrehuliuvannia konfliktu na Donbasi: mizhnarodnyi dosvid ta ukrainski realii. [Models and price of conflict regulation in Donbas: international experience and Ukrainian realia]. Kyiv: Miznarodnyi tsentr perspektyvnykh doslidzhen. [in Ukrainian].

Oktisiuk, A. (2016, 12 avgusta). Posledstviia krymskoi diversii Ukrainu zhdut chetyre stsenariia razvitiia sobytii. [Consequences of Crimean "diversion": Four scenarios of actions' development are waiting for Ukraine]. Apostrof. Retrieved from https://apostrophe.ua/article/politics/2016o8-12/posledstviya-kryimskoy-diversii-ukrainu-jdut-chetyire-stsenariya-razvitiya-sobyitiy/6735 [in Russian]

UN DDR. Inter-Agency Working Group on Disarmament, Demobilization and Reintegration. (2005). DDR briefing note for senior managers on the integrated disarmament, demobilization and reintegration standards. Retrieved from http://unddr.org/uploads/documents/SMN-FINAL.pdf [in English]

United Nations Disarmament, Demobilization and Reintegration Resource Centre, UN DDR. (2014). Operational guide to the integrated disarmament, demobilization and reintegration standards. Retrieved from https://www.unddr.org/uploads/documents/Operational\%2oGuide.pdf [in English]

UNHCR's Centre for Documentation and Research (CDR). (1997.) Reintegration in the Transition from War to Peace. Retrieved from www.refworld.org/pdfid/3ae6b31f8.pdf [in English]

Verkhovna rada Ukrainy. (2018). Zakon Ukrainy Pro osoblyvosti derzhavnoi polityky iz zabezpechennia derzhavnoho suverenitetu Ukrainy na tymchasovo okupovanykh terytoriiakh u Donetskii ta Luhanskii oblastiakh [Legislation of Ukraine, Ukraine state sovereignty maintenance special policy on the temporary occupied territories of Donbass and Luhansk regions]. Retrieved from https://zakon.rada.gov.ua/laws/show/2268-19 [in Ukrainian]

Nina Rzhevska,

National Aviation University, Kyiv, Ukraine ORCID: https://orcid.org/oooo-Ooo2-7671-3221

\section{Occupied territories reintegration model: world experience and Ukrainian variant}

The article is uncovering core meaning of occupied and deoccupied territories reintegration process, determines current state and peculiarity of conflict on the East of Ukraine. Conceptually reintegration is determined here as a process of citizens' comeback to social, cultural, economic and political life of the country of their origin. There are analyzed its componential parts and instruments for realization, also presented and assessed 
the foreign reintegration models of occupied and deoccupied territories, determined their level of acceptance for Ukraine. There was made an attempt in order to find the most effective model for Donbass reintegration, which could not only stimulate demilitarization, renewing of state control on these territories, but also prevent from separation movements, stimulate comeback and integration of citizens into Ukrainian informational, cultural, economic and political space.

The lack of common position among the citizens on the optimal way to restore the territorial integrity of Ukraine still remains to be a problem which forms more optimal, during the whole conflict period terms for creating a complex state policy on this issue, considering the present demand of all the Ukrainian citizens and mentioned above common grounds.

That is why, the urgent need is the presence of common state strategy on the armed conflict solution in the East of Ukraine and its consequences elimination, among which is the reintegration of these territories, taking into account the compromises which are agreed by Ukrainian citizens, key solutions of not only military but also political, economic and informational dimension of the conflict and international experience of territories' integration.

Complex strategy on territorial integrity restoring and Donbas reintegration will cover the vital actions due to the all conflict dimensions, compromises that will get the social support, includes current domestic political and international process features, international experience on peace restoration and reintegration, and will form single state approach to solve this problem.

Keywords: reintegration, occupied territories, deocuppied territories, state strategy, reintegration model

Додаток А

Реалізація стратегій кожного учасника

\begin{tabular}{|c|c|c|c|c|c|}
\hline № & & S1 - Україна & $\mathrm{S} 2-\mathrm{P} \Phi$ & $\mathrm{S}_{3}-\mathrm{EC}$ & $\begin{array}{l}\mathrm{S} 4-\text { ЛНР i } \\
\text { ДНР }\end{array}$ \\
\hline 1. & $\mathrm{X}_{11 \mathrm{X}} 21 \mathrm{X}_{31 \mathrm{X}} 41$ & 2,8 & 2,8 & 1,8 & 3,6 \\
\hline 2. & $\mathrm{x} 11 \mathrm{x} 21 \mathrm{X} 31 \mathrm{x} 42$ & 2,4 & 2,6 & 1,4 & 3,6 \\
\hline 3. & $\mathrm{x} 11 \times 21 \times 32 \times 41$ & 3 & 3,6 & 1,8 & 4,2 \\
\hline 4. & $\mathrm{x} 11 \times 21 \times 32 \times 42$ & 1,6 & 3,4 & 1,4 & 4,2 \\
\hline 5. & $\mathrm{x} 11 \mathrm{X} 21 \mathrm{X} 33 \mathrm{X} 41$ & 2,8 & 2,8 & 1,8 & 3,4 \\
\hline 6. & $\mathrm{x} 11 \mathrm{x} 21 \mathrm{X} 33 \mathrm{x} 42$ & 2,4 & 3,2 & 1,4 & 3,4 \\
\hline 7. & $\mathrm{x} 11 \mathrm{X} 22 \times 31 \mathrm{X} 41$ & 4 & 2,8 & 3 & 3 \\
\hline 8. & $\mathrm{x} 11 \times 22 \times 31 \times 42$ & 3,6 & 3,4 & 2,6 & 3 \\
\hline 9. & $\mathrm{x} 11 \mathrm{x} 22 \times 32 \times 41$ & 3,2 & 3,6 & 3 & 3,6 \\
\hline 10. & $\mathrm{x} 11 \times 22 \times 32 \times 42$ & 3,6 & 2,6 & 2,6 & 3,6 \\
\hline 11. & $\mathrm{x} 11 \mathrm{X} 22 \mathrm{2} 33 \mathrm{X} 41$ & 4 & 3,6 & 3 & 2,8 \\
\hline 12. & $\mathrm{x} 11 \mathrm{x} 22 \times 33 \times 42$ & 3,6 & 3,4 & 2,6 & 2,8 \\
\hline 13. & $\mathrm{x} 11 \times 23 \times 31 \times 41$ & 3,1 & 3,4 & 2,4 & 3,9 \\
\hline 14. & $\mathrm{x} 11 \times 23 \times 31 \times 42$ & 2,7 & 4 & 2 & 3,9 \\
\hline 15. & $\mathrm{x} 11 \times 23 \times 32 \times 41$ & 2,3 & 4,2 & 2,4 & 4,5 \\
\hline 16. & $\mathrm{x} 11 \times 23 \times 32 \times 42$ & 2,1 & 4 & 2 & 4,5 \\
\hline 17. & $\mathrm{x} 11 \times 23 \times 33 \times 41$ & 3,1 & 3,4 & 2,4 & 3,7 \\
\hline 18. & $\mathrm{x} 11 \times 23 \times 33 \times 42$ & 2,7 & 3,2 & 2 & 3,7 \\
\hline 19. & $\mathrm{x} 12 \mathrm{x} 21 \mathrm{X} 31 \mathrm{X} 41$ & 3,4 & 2,8 & 3 & 2,7 \\
\hline 20. & $\mathrm{x} 12 \times 21 \times 31 \times 42$ & 3 & 2,6 & 2,6 & 2,7 \\
\hline 21. & $\mathrm{x} 12 \times 21 \times 32 \times 41$ & 2,6 & 3,6 & 2,4 & 3,3 \\
\hline 22. & $\mathrm{x} 12 \times 21 \times 32 \times 42$ & 3 & 3,4 & 2,6 & 3,3 \\
\hline 23. & $\mathrm{x} 12 \times 21 \times 33 \times 41$ & 3,4 & 2,8 & 3 & 2,5 \\
\hline 24. & $\mathrm{x} 12 \times 21 \times 33 \times 42$ & 3 & 2,6 & 2,6 & 2,5 \\
\hline
\end{tabular}


Acta de Historia \& Politica: Saeculum XXI

\begin{tabular}{|c|c|c|c|c|c|}
\hline № & & S1 - Україна & $\mathrm{S} 2-\mathrm{P} \Phi$ & $\mathrm{S}_{3}-\mathrm{EC}$ & $\begin{array}{c}\mathrm{S} 4-\text { - ЛНР i } \\
\text { ДНР }\end{array}$ \\
\hline 25. & $\mathrm{x} 12 \times 22 \times 31 \times 41$ & 4,6 & 2,8 & 4,2 & 2,1 \\
\hline 26. & $\mathrm{x} 12 \times 22 \times 31 \mathrm{x} 42$ & 4,2 & 2,6 & 3,8 & 2,1 \\
\hline 27. & $\mathrm{x} 12 \times 22 \times 32 \times 41$ & 3,8 & 3,6 & 4,2 & 2,7 \\
\hline 28. & $\mathrm{x} 12 \times 22 \times 32 \times 42$ & 3,4 & 3,4 & 3,8 & 2,7 \\
\hline 29. & $\mathrm{x} 12 \times 22 \times 33 \times 41$ & 4,6 & 2,8 & 4,2 & 1,9 \\
\hline 30. & $\mathrm{x} 12 \times 22 \times 33 \times 42$ & 4,2 & 2,6 & 3,8 & 1,9 \\
\hline 31. & $\mathrm{x} 12 \times 23 \times 31 \times 41$ & 3,7 & 3,4 & 3,6 & 3 \\
\hline 32. & $\mathrm{x} 12 \times 23 \times 31 \mathrm{x} 42$ & 3,3 & 3,2 & 3,2 & 3 \\
\hline 33. & $\mathrm{x} 12 \times 23 \times 32 \times 41$ & 2,9 & 4,2 & 3,6 & 3,6 \\
\hline 34. & $\mathrm{x} 12 \times 23 \times 32 \times 42$ & 3,3 & 4 & 3,2 & 3,6 \\
\hline 35. & x12X23×33X41 & 3,7 & 3,4 & 3,6 & 2,8 \\
\hline 36. & $\mathrm{x} 12 \times 23 \times 33 \times 42$ & 3,3 & 3,8 & 2,6 & 2,8 \\
\hline 37. & $\mathrm{x} 13 \times 21 \times 31 \times 41$ & 2,2 & 3,1 & 1,8 & 3,9 \\
\hline 38. & $\mathrm{x} 13 \times 21 \times 31 \times 42$ & 1,8 & 2,9 & 2,6 & 3,9 \\
\hline 39. & $\mathrm{x} 13 \times 21 \times 32 \times 41$ & 1,4 & 3,9 & 3 & 4,5 \\
\hline 40. & $\mathrm{x} 13 \times 21 \times 32 \times 42$ & 1 & 3,7 & 2,6 & 4,5 \\
\hline 41. & $\mathrm{x} 13 \times 21 \times 33 \times 41$ & 2,2 & 3,1 & 3 & 3,7 \\
\hline 42. & $\mathrm{x} 13 \times 21 \times 33 \times 42$ & 1,8 & 2,9 & 2,6 & 3,7 \\
\hline 43. & $\mathrm{x} 13 \times 22 \times 31 \times 41$ & 3,4 & 3,1 & 4,2 & 3,3 \\
\hline 44. & $\mathrm{x} 13 \times 22 \times 31 \times 42$ & 3 & 2,9 & 3,8 & 3,3 \\
\hline 45. & $\times 13 \times 22 \times 32 \times 41$ & 6,9 & 3,9 & 4,2 & 3,9 \\
\hline 46. & $\mathrm{x} 13 \times 22 \times 32 \times 42$ & 2,2 & 3,7 & 3,8 & 3,9 \\
\hline 47. & $\times 13 \times 22 \times 33 \times 41$ & 2,4 & 3,1 & 4,2 & 3,1 \\
\hline 48. & $\times 13 \times 22 \times 33 \times 42$ & 3 & 2,9 & 3,8 & 3,1 \\
\hline 49. & $\times 13 \times 23 \times 31 \times 41$ & 2,5 & 3,7 & 3,6 & 4,2 \\
\hline 50. & $\times 13 \times 23 \times 31 \times 42$ & 2,1 & 4,3 & 3,2 & 4,2 \\
\hline 51. & $\times 13 \times 23 \times 32 \times 41$ & 1,7 & 4,5 & 3,6 & 4,8 \\
\hline 52. & $\times 13 \times 23 \times 32 \times 42$ & 2,1 & 4,3 & 3,2 & 4,8 \\
\hline 53. & 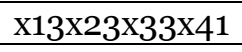 & 1,7 & 3,7 & 3,6 & 4 \\
\hline 54. & $\mathrm{x} 13 \times 23 \times 33 \times 42$ & 2,1 & 3,5 & 3,2 & 4 \\
\hline 55. & $\mathrm{x} 14 \mathrm{X} 21 \mathrm{x} 31 \mathrm{x} 41$ & 2,5 & 2,8 & 2,7 & 3,6 \\
\hline 56. & $\mathrm{x} 14 \times 21 \times 31 \times 42$ & 2,1 & 2,6 & 2,3 & 3,6 \\
\hline 57. & $\mathrm{x} 14 \times 21 \times 32 \times 41$ & 1,7 & 3,6 & 2,7 & 4,2 \\
\hline 58. & $\mathrm{x} 14 \times 21 \times 32 \times 42$ & 1,3 & 3,4 & 2,3 & 4,2 \\
\hline 59. & $\mathrm{x} 14 \times 21 \times 33 \times 41$ & 2,5 & 2,8 & 2,7 & 3,4 \\
\hline 60. & X14X21X33X42 & 2,1 & 3,2 & 2,3 & 3,4 \\
\hline 61. & $\mathrm{x} 14 \times 22 \times 31 \mathrm{X} 41$ & 3,7 & 2,8 & 3,9 & 3 \\
\hline 62. & $\mathrm{x} 14 \times 22 \times 31 \times 42$ & 1,8 & 3,4 & 3,5 & 3 \\
\hline 63. & $\mathrm{x} 14 \times 22 \times 32 \times 41$ & 1,4 & 3,6 & 3,9 & 3,6 \\
\hline 64. & $\mathrm{x} 14 \times 22 \times 32 \times 42$ & 1 & 2,6 & 3,5 & 3,6 \\
\hline 65. & $\mathrm{x} 14 \times 22 \times 33 \times 41$ & 2,2 & 2,8 & 3,9 & 2,8 \\
\hline 66. & $\mathrm{x} 14 \times 22 \times 33 \times 42$ & 1,4 & 2,6 & 3,5 & 2,8 \\
\hline 67. & $\mathrm{x} 14 \times 23 \times 31 \times 41$ & 2,2 & 3,4 & 3,3 & 3,9 \\
\hline 68. & X14X23×31X42 & 2,4 & 3,2 & 2,9 & 3,9 \\
\hline 69. & $\mathrm{x} 14 \times 23 \times 32 \times 41$ & 2 & 4,2 & 3,3 & 4,5 \\
\hline 70. & $\mathrm{x} 14 \times 23 \times 32 \times 42$ & 1,6 & 4 & 2,9 & 4,5 \\
\hline 71. & $\mathrm{x} 14 \times 23 \times 33 \times 41$ & 2,8 & 3,4 & 3,3 & 3,7 \\
\hline 72. & $\times 14 \times 23 \times 33 \times 42$ & 2,4 & 3,2 & 2,9 & 3,7 \\
\hline
\end{tabular}

